\title{
Knowledge, and attitude towards human papilloma virus infection among pharmacy students in Mumbai, India
}

\section{Dnyanesh Limaye 1,2,3,**, Drashty Mehta $^{5}$, Shakshi Singh ${ }^{5}$, Apurva Pardeshi ${ }^{5}$, Tanvi Patil , Arlan Sydymanov', Vaidehi Limaye ${ }^{1}$, Ravi Shankar Pitani ${ }^{6}$, Sushama Sathe ${ }^{7}$, Atul Kapadi ${ }^{7}$, Gerhard Fortwengel ${ }^{1}$}

\author{
${ }^{1}$ Clinical Research and Epidemiology, Hochschule Hannover, Hannover, Lower Saxony, Germany \\ ${ }^{2}$ Hannover Medical School, Hannover, Germany \\ ${ }^{3}$ Helmholtz Centre for Infection Research, Braunschweig, Germany \\ ${ }^{4}$ Hannover Biomedical Research School, Hannover, Germany \\ ${ }^{5}$ Department of Pharmacy, Institute of Chemical Technology, Mumbai, Maharashtra, India \\ ${ }^{6}$ Community Medicine, Sri Ramachandra University, Chennai, India \\ ${ }^{7}$ Health Sciences Department, Research Institute of Health Sciences and Management and Chetan Dattaji Gaikwad \\ Institute of Management Studies, Pune, Maharashtra, India
}

Received: 08 May 2018

Accepted: 30 May 2018

*Correspondence:

Dr. Dnyanesh Limaye,

E-mail: dnyanesh.limaye@hs-hannover.de

Copyright: ( $)$ the author(s), publisher and licensee Medip Academy. This is an open-access article distributed under the terms of the Creative Commons Attribution Non-Commercial License, which permits unrestricted non-commercial use, distribution, and reproduction in any medium, provided the original work is properly cited.

\footnotetext{
ABSTRACT

Background: Human papillomavirus (HPV) is a common sexually transmitted infection (STI) that may cause cervical cancer and other malignancies including those of the vulva, anus, vagina, penis, head and neck. In most Asian countries including India, cervical cancer is the second most common cancer in women. Awareness about HPV and cervical cancer, use of vaccines can be very helpful in prevention, control and early diagnosis of cervical cancer. Methods: A cross-sectional study was carried out among students from Mumbai University, India during May - June 2017. Two hundred students were approached to participate in the study of which 142 were selected to participate (males: 54; females: 88). Pretested questionnaire was distributed and collected data was analyzed using IBM SPSS version 23.

Results: Participants had fair knowledge (61\% average) about HPV, whereas knowledge about symptoms, prevention and spread of HPV was very poor i.e. $18 \%$. Knowledge about HPV vaccine was $50 \%$ and $78 \%$ participants had positive attitude for HPV vaccine.

Conclusions: This study showed the lacunas in the pharmacy curriculum and urgent need to create awareness of HPV among bachelor of pharmacy students from Mumbai University.
}

Keywords: HPV, India, Mumbai, Pharmacy, Students, Vaccine

\section{INTRODUCTION}

Human papillomavirus (HPV) is a common sexually transmitted infection (STI) that may cause cervical cancer and other malignancies including those of the vulva, anus, vagina, penis, head and neck. ${ }^{1-3}$ Unlike many other cancers, cervical cancer occurs early and strikes at the productive period of a woman's life. The incidence rises in 30-34 years of age and peaks at 55-65 years, with a median age of 38 years (age 21-67 years). Estimates suggest that more than $80 \%$ of the sexually active women acquire genital HPV by 50 years of age. ${ }^{4}$ Skin-to-skin 
genital contact is a well-recognized mode of transmission for HPV. ${ }^{5}$

Cervical cancer is the fourth leading cancer in women globally, but its major burden is felt in the low- and middle-income countries (LMICs) with very limited resources to introduce and sustain effective populationbased cervical cancer screening programs. In most Asian countries including India, cervical cancer is the second most common cancer in women. ${ }^{6}$ Cervical cancer accounts for 528,000 cases in the world (445,000 cases in LMICs); it causes 265,700 estimated deaths annually globally, with 230,200 (86.6\%) deaths in the LMICs. ${ }^{7}$ Cervical cancer is ranked as the most frequent cancer in women in India. India has a population of approximately 365.71 million women above 15 years of age, who are at risk of developing cervical cancer. The current estimates indicate approximately 132,000 new cases diagnosed and 74,000 deaths annually in India, accounting to nearly $1 / 3$ of the global cervical cancer deaths. ${ }^{8}$

The majority of the Indian women diagnosed with cervical cancer have never been screened for the disease and around $70 \%$ of these cases present in advance stages due to absence of any organized cervical cancer screening program. It has been estimated that there will be around 205496 new cases and 119097 deaths due to cervical carcinoma by 2020 in India. $^{9}$ Despite these; there are no large scale public health surveillance programs in cervical cytological screening and human papillomavirus (HPV) typing in India. Awareness about HPV and cervical cancer, use of vaccines can be very helpful in prevention, control and early diagnosis of cervical cancer. Young students could be educated to create awareness in the society regarding HPV and cervical cancer.

The objective of this study was therefore to determine the knowledge, and attitudes, towards human papilloma virus among university students in Mumbai, India which can be utilized to plan the education and awareness strategies for them.

\section{METHODS}

\section{Study design and respondents}

This descriptive study was performed in May - June 2017, among pharmacy students from Mumbai University, India. The study protocol was approved by V.
V. research Independent Ethics Committee, Mumbai, India. Two hundred students were contacted by study team member in their classrooms and were given a brief introduction about the research project. Those who desired to participate were explained the purpose and objectives of the study. On the basis of the eligibility criterion (those who gave a written informed consent and are registered students of Mumbai University) 142 students were selected for the present study.

\section{Study instrument}

The survey questionnaire was prepared in English after reviewing the literature for similar studies. The questionnaire was framed to gather information on demographics and knowledge and attitude toward human papilloma virus infection. A pilot study was done with a sample of 30 students, to know the average time required for face to face interview for completing the questionnaire and to ensure that it is appropriate and understandable to students. Pilot population was not part of the final study.

\section{Collection of data}

Students were face to face interviewed in the student office with prior appointment by a study member from a team of 5 trained Bachelor of Pharmacy Students. The purpose of the research was explained to the respondents; anonymity and confidentiality were guaranteed and maintained. The researchers complied with the international ethical guidelines for research. The data was recorded into the predesigned data report form (DRF) by interviewers.

\section{Data entry and analysis}

Collected data from individual DRF was entered into Microsoft excel and was verified by the authors other than interviewers. Data was analyzed by using descriptive statistical methods and a bivariate analysis was conducted with all relevant independent variables and Odds Ratios (OR) and their respective 95\% Confidence Intervals (CI) were calculated. P-value $\leq 0.05$ was considered as significant. IBM SPSS version 23 was used for statistical analysis.

\section{RESULTS}

Table 1: Demographic characteristics of the participants $(n=142)$.

\begin{tabular}{|c|c|c|c|c|c|c|}
\hline Variable & Expected answer & Male n (\%) & Female n (\%) & Total n (\%) & $\chi^{2}$ value & $\mathrm{p}$-value \\
\hline Gender & & $54(38)$ & $88(62)$ & $142(100)$ & NA & NA \\
\hline \multicolumn{7}{|l|}{ Education } \\
\hline $\mathrm{BS}$ & & $38(70)$ & $72(82)$ & $110(78)$ & \multirow{3}{*}{3.7} & \multirow{3}{*}{0.2} \\
\hline MS & & $8(15)$ & $11(12)$ & $19(13)$ & & \\
\hline $\mathrm{Ph} \underline{\underline{D}}$ & & $8(15)$ & $5(6)$ & $13(9)$ & & \\
\hline Have you heard about HPV? & yes & $36(67)$ & $61(69)$ & $97(68)$ & 0.109 & 0.742 \\
\hline
\end{tabular}


Table 1 represents demographic characteristics of participants for this study. Response rate for this study was $71 \%(142 / 200)$. Out of a total 142 participants $62 \%$ (88) were female and $38 \%$ (54) were male participants. Maximum participants were from bachelor of pharmacy study program $(78 \%)$.

The association of gender with their education was not significant $(\mathrm{P}=0.153)$. Out of 142 participants only 97 $(68 \%)$ were aware about HPV which was used for further questions and response analysis.
As shown in Table 2, respondents had fair knowledge (61\% average) about HPV. Out of 8 questions related to knowledge about HPV only for one question i.e. "Is HPV sexually transmitted?" most of the participants (93/97; $96 \%$ ) gave the correct response "yes". For questions related to occurrence, incidence and possibility of HPV occurring without symptoms more than $50 \%$ respondents gave incorrect responses. For questions related to cause, gender, genital warts and other cancers more than $60 \%$ respondents gave correct responses. There were no gender differences related to knowledge about HPV.

Table 2: Knowledge about HPV.

\begin{tabular}{|c|c|c|c|c|c|c|}
\hline Variable & $\begin{array}{l}\text { Expected } \\
\text { answer }\end{array}$ & $\begin{array}{l}\text { Male } \\
67(\%)\end{array}$ & $\begin{array}{l}\text { Female } \\
69(\%)\end{array}$ & $\begin{array}{l}\text { Total } \\
97(100)\end{array}$ & $\chi^{2}$ value & p-value \\
\hline Is HPV sexually transmitted? & yes & $35(97)$ & $58(95)$ & $93(96)$ & 0.3 & 0.6 \\
\hline Are HPV infections rare in India? & no & $12(33)$ & $22(36)$ & $34(35)$ & 0.1 & 0.8 \\
\hline Does HPV cause cervical cancer? & yes & $27(75)$ & $44(72)$ & $71(73)$ & 0.1 & 0.7 \\
\hline $\begin{array}{l}\text { Can HPV infect both men and } \\
\text { women? }\end{array}$ & yes & $19(53)$ & $41(67)$ & $60(62)$ & 2.0 & 0.2 \\
\hline $\begin{array}{l}\text { Is the incidence of HPV highest } \\
\text { among women in their 20s and } \\
\text { 30s? }\end{array}$ & yes & $15(42)$ & $27(44)$ & $42(43)$ & 0.1 & 0.8 \\
\hline $\begin{array}{l}\text { Can a HPV infection occur without } \\
\text { symptoms? }\end{array}$ & yes & $11(30)$ & $21(34)$ & $32(33)$ & 0.1 & 0.7 \\
\hline $\begin{array}{l}\text { Does HPV cause genital (external } \\
\text { organs of reproduction e.g. testes) } \\
\text { warts? }\end{array}$ & yes & $29(80)$ & $46(75)$ & $75(77)$ & 0.3 & 0.6 \\
\hline $\begin{array}{l}\text { Can HPV cause other genital } \\
\text { cancers (penis, anus)? }\end{array}$ & yes & $24(67)$ & $41(67)$ & $65(67)$ & 0.0 & 1.0 \\
\hline Average knowledge & & $61 \%$ & & & & \\
\hline
\end{tabular}

Table 3: Knowledge about symptoms, prevention and spread of HPV.

\begin{tabular}{|lllllll|}
\hline Variable & Expected answer & $\begin{array}{l}\text { Male } \\
\#(\%)\end{array}$ & $\begin{array}{l}\text { Female } \\
\#(\%)\end{array}$ & Total & $\chi^{2}$ value & p-value \\
\hline $\begin{array}{l}\text { What are the health problems } \\
\text { associated with HPV? }\end{array}$ & $\begin{array}{l}\text { All i.e. cervical cancer, } \\
\text { penile cancer, Genital } \\
\text { warts, HIV }\end{array}$ & $2(6)$ & $5(8)$ & $7(7)$ & 0.2 & 0.6 \\
\hline $\begin{array}{l}\text { What can be done for } \\
\text { prevention of HPV? }\end{array}$ & $\begin{array}{l}\text { All i.e. abstinence, } \\
\text { vaccination, use of } \\
\text { condoms }\end{array}$ & $8(22)$ & $8(13)$ & $16(16)$ & 1.4 & 0.2 \\
\hline $\begin{array}{l}\text { How does spread/transmission } \\
\text { of HPV happens? }\end{array}$ & $\begin{array}{l}\text { Genital skin and skin } \\
\text { contact }\end{array}$ & $12(33)$ & $19(31)$ & $31(32)$ & 0.1 & 0.8 \\
\hline Average knowledge & & $18 \%$ & & & & \\
\hline
\end{tabular}

As seen from the Table 3, participants had very poor knowledge (18\% average) about symptoms, prevention and spread of HPV.

Ninety three percent participants were not able to correctly identify the health problems associated with HPV. Only $16 \%$ and $32 \%$ of the participants could correctly select right choices for prevention of HPV and spread of HPV respectively.
As shown in Table 4 participants had fair knowledge (50\%) about HPV vaccine.

Out of 5 questions related to HPV vaccine, for 2 questions related to vaccination and screening for cervical cancer and HPV vaccination before commencing sexual intercourse $67 \%$ participants gave incorrect answers. 
Seventy three percent, $62 \%$ and $50 \%$ participants correctly answered that there is a vaccine to protect against HPV, it prevents the chances of cervical cancers and it is not only for people who are sexually active respectively.

Table 4: Knowledge about HPV vaccine.

\begin{tabular}{|c|c|c|c|c|c|c|}
\hline Variable & $\begin{array}{l}\text { Expected } \\
\text { answer }\end{array}$ & $\begin{array}{l}\text { Male } \\
\#(\%)\end{array}$ & $\begin{array}{l}\text { Female } \\
\#(\%)\end{array}$ & Total & $\chi^{2}$ value & p-value \\
\hline Is there a vaccine that protects against HPV? & yes & $25(69)$ & $46(75)$ & $71(73)$ & 0.4 & 0.5 \\
\hline $\begin{array}{l}\text { The HPV vaccine prevents the chances of } \\
\text { cervical cancers }\end{array}$ & yes & $22(61)$ & $38(62)$ & $60(62)$ & 0.0 & 0.9 \\
\hline $\begin{array}{l}\text { Once vaccinated, women no longer have to be } \\
\text { screened for cervical cancer }\end{array}$ & no & $11(30)$ & $21(34)$ & $32(33)$ & 0.1 & 0.7 \\
\hline $\begin{array}{l}\text { The HPV vaccine is only for people who are } \\
\text { sexually active }\end{array}$ & no & $20(55)$ & $29(47)$ & $49(50)$ & 0.6 & 0.4 \\
\hline $\begin{array}{l}\text { Should the HPV vaccine be given before } \\
\text { commencing sexual intercourse? }\end{array}$ & yes & $15(42)$ & $17(28)$ & $32(33)$ & 1.9 & 0.2 \\
\hline Average knowledge & & $50 \%$ & & & & \\
\hline
\end{tabular}

Table 5: Attitude about HPV vaccine.

\begin{tabular}{|c|c|c|c|c|c|c|}
\hline Variable & $\begin{array}{l}\text { Expected } \\
\text { answer }\end{array}$ & $\begin{array}{l}\text { Male } \\
\#(\%)\end{array}$ & $\begin{array}{l}\text { Female } \\
\#(\%)\end{array}$ & Total & $\chi^{2}$ value & p-value \\
\hline $\begin{array}{l}\text { If my friends knew about the HPV } \\
\text { vaccine, they would approve of me } \\
\text { getting vaccinated against HPV. }\end{array}$ & yes & $27(75)$ & $48(79)$ & $75(77)$ & 0.2 & 0.7 \\
\hline $\begin{array}{l}\text { If my parent knew about the HPV } \\
\text { vaccine, they would approve of me } \\
\text { getting vaccinated against HPV. }\end{array}$ & yes & $28(78)$ & $47(77)$ & $75(77)$ & 0.0 & 0.9 \\
\hline $\begin{array}{l}\text { If my doctor knew about the HPV } \\
\text { vaccine, he/she would approve of } \\
\text { me getting vaccinated against HPV }\end{array}$ & yes & $28(78)$ & $49(80)$ & 77 (79) & 0.1 & 0.8 \\
\hline Average & & 78 & & & & \\
\hline
\end{tabular}

As seen in Table 5, participants had overall good attitude about getting vaccinated against HPV.

\section{DISCUSSION}

Cervical cancer is the fourth leading cancer in women globally, but its major burden is felt in the low- and middle-income countries (LMICs) with very limited resources to introduce and sustain effective populationbased cervical cancer screening programs. The knowledge that persistent infection with one of the oncogenic, high-risk types of human papillomaviruses (HPVs) is the 'necessary' cause of cervical cancer, implying that the infection is obligatory to initiate the carcinogenic process, has opened up an exciting and effective means of primary prevention using vaccination. ${ }^{10,11}$

These developments linking HPV to cervical cancer are not known in the community and there is no existing concerted effort to develop public health campaigns to increase this awareness. Community awareness and buy- in is critical to the introduction of newer strategies for cervical cancer prevention. ${ }^{12}$

Present study indicated overall fair awareness about HPV, and HPV vaccination. Overall awareness (61\%) seen in this study was lesser than the study done in Karnataka which reported awareness of $75 \%$. Study done by Pandey et al showed that $89 \%$ participants knew the etiology of HPV as compared to $73 \%$ from the present study. Both studies showed similar percentage of participants being aware about availability of HPV vaccine. ${ }^{13}$

The differences seen in both studies could have originated because Karnataka study was done among medial students as against pharmacy students in the present study. HPV awareness in the present study (61\%) was much better as compared to a study done among general population (12\%) in Odisha, India. ${ }^{12}$ Awareness in present study was better than the study done among university students from Lahore, Pakistan which had 57\% awareness of HPV. Only $32 \%$ participants had correct 
knowledge about spread of HPV as compared to $44 \%$ from study by Khan et al. ${ }^{14}$

\section{CONCLUSION}

The results of this study revealed a fair understanding among pharmacy students about HPV. Knowledge about symptoms, prevention and spread of HPV was very poor; even $50 \%$ students did not have knowledge about HPV vaccine. This study showed the lacunas in the pharmacy curriculum and urgent need to create awareness of HPV among bachelor of pharmacy students from Mumbai University.

\section{Funding: No funding sources}

Conflict of interest: None declared

Ethical approval: The study was approved by the Institutional Ethics Committee

\section{REFERENCES}

1. Bosch FX, Lorincz A, Munoz N, Meijer CJ, Shah KV. The causal relation between human papillomavirus and cervical cancer. J Clin Pathol. 2002;55:244-65.

2. de Martel C, Ferlay J, Franceschi S. Global burden of cancers attributable to infections in 2008: a review and synthetic analysis. Lancet Oncol. 2012;13(6):607-15.

3. Park I, Introcaso C, Dunne E. Human papilloma virus and genital warts:a review of the evidence for the 2015 centers for disease control and prevention Sexually transmitted diseases treatment guidelines. Clin Infect Dis. 2015;61(8):S849-55.

4. Singh N. HPV and Cervical cancer - prospects for prevention through vaccination. Indian $\mathbf{J} \mathrm{Med}$ Paediatr Oncol. 2005;26:20-3.

5. W.H.O. Human Papilloma virus (HPV) and Cervical Cancer, 2015 (cited 2016 15thFeburary); Available at http://www.who.int/mediacentre/factsheets/fs 380/en/.

6. Bruni L, Barrionuevo-Rosas L, Albero G. ICO (Institute Català d'Oncologia) Information Centre on HPV and Cancer (HPV Information Centre). Human
Papillomavirus and Related Diseases Report- World. Summary Report. 2015. Available at http://www.hpvcentre.net/statistics/reports/XWX.pdf . Accessed on September 21, 2016.

7. Ferlay J, Soerjomataram I, Ervik M. GLOBOCAN 2012 v1.0, Cancer Incidence and Mortality Worldwide: IARC Cancer Base No. 11. Lyon: International Agency for Research on Cancer; 2013.

8. WHO/ICO Information Centre on HPV and Cervical Cancer (HPV Information Centre). Summary report on HPV and cervical cancer statistics in India 2007. Available at http://www.who.int/hpvcentre. Assessed on May 1, 2008.

9. Ferlay J, Bray F, Pisani P. GLOBOCAN, 2002 Cancer Incidence, Mortality and Prevalence Worldwide, Version 1. 0. IARC Cancer Base No. 5, IARC Press, Lyon, France; 2004.

10. Muñoz N, Bosch F, de Sanjosé S. Epidemiologic classification of human papillomavirus types associated with cervical cancer. $\mathrm{N}$ Engl J Med. 2003;348:518-27.

11. International Agency for Research on Cancer; IARC Monographs on the Evaluation of Carcinogenic Risks to Humans: Human Papillomaviruses. Lyon: IARC; 2007.

12. Khanna N, Ramaseshan A, Arnold S. Community awareness of HPV screening and vaccination in Odisha. Obstet Gynecol Inte. 2015. Article ID 694560.

13. Pandey D, Vanya V, Bhagat S. Awareness and Attitude towards Human Papillomavirus (HPV) Vaccine among Medical Students in a Premier Medical School in India. PLoS ONE 7(7): e40619.

14. Khan T, Buksh M, Rehman I. Knowledge, attitudes and perception towards human papilloma virus among university students in Pakistan. Papilloma Virus Res. 2016;2:122-7.

Cite this article as: Limaye D, Mehta D, Singh S, Pardeshi A, Patil T, Sydymanov A, et al. Knowledge, and attitude towards human papilloma virus infection among pharmacy students in Mumbai, India. Int J Reprod Contracept Obstet Gynecol 2018;7:2532-6. 